
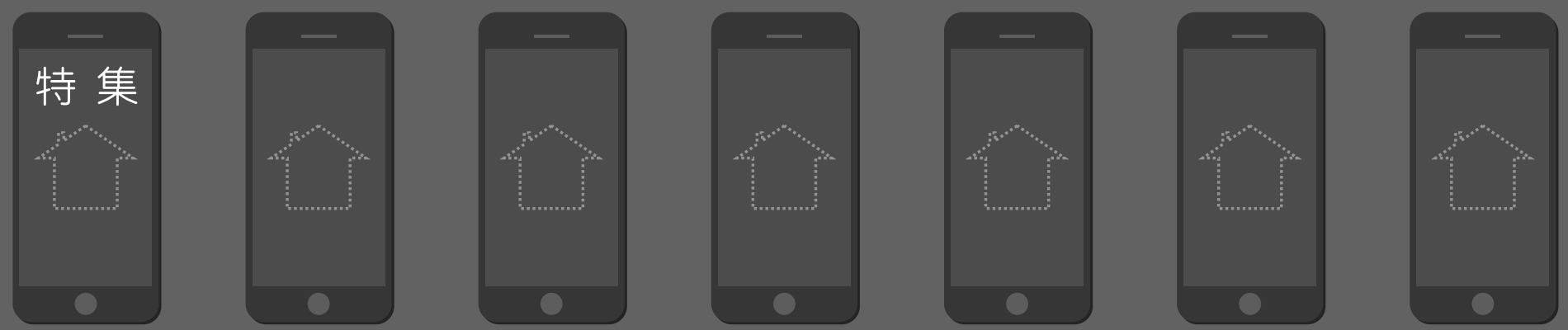

\title{
モバイルデバイスの 最新動向
}

O
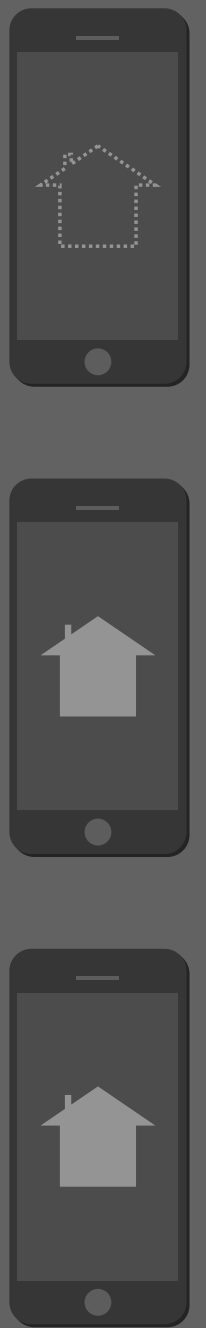

2世帯に1世帯がスマートフオンを所有一ースマートフオンやタブレットをはじめとす るモバイルデバイスは近年, 急速に社会に浸透しています。ネット利用も, スマホ・タブ レットによるものが急増しています.これには, デバイスの小型・高機能化の流れがあり, 従来の情報受信端末としての機能に加え，情報の送り手としての機能が充実してきてい ることが背景にあるといえましょう.

本特集では，最新のスマートフオン・タブレットの進化を支える技術について解説を行 います．情報の入出力技術や他デバイスとの情報共有技術に加え，モバイルデバイスによ る情報の活用事例についても紹介します。

本特集の構成は, 次のようになつています. まず第1章で, モバイルデバイスの最近の 進化の概要を説明します. 第2章で，モバイル端末上のカメラ技術について，最新技術を 紹介します. 第3章では, いまやモバイルデバイスでは欠かすことのできないセンサ技術 について解説します。第4章・第5章ではそれぞれ，発展著しいモバイルディスプレイ技 術とオーディオ技術について，その最新事例を解説します、第6章では，映像情報メディ アをモバイルデバイスと他のデバイス（テレビや車載ディスプレイなど）で共有するため の技術について説明します．最後に第7章では，モバイルデバイス上の映像情報メディア 技術のディジタルアーカイブズへの活用事例について紹介します。

なお，本特集の企画は，春山前編集幹事，山田編集幹事，佐藤編集幹事と私が担当いた しました.

編集幹事 川田亮一
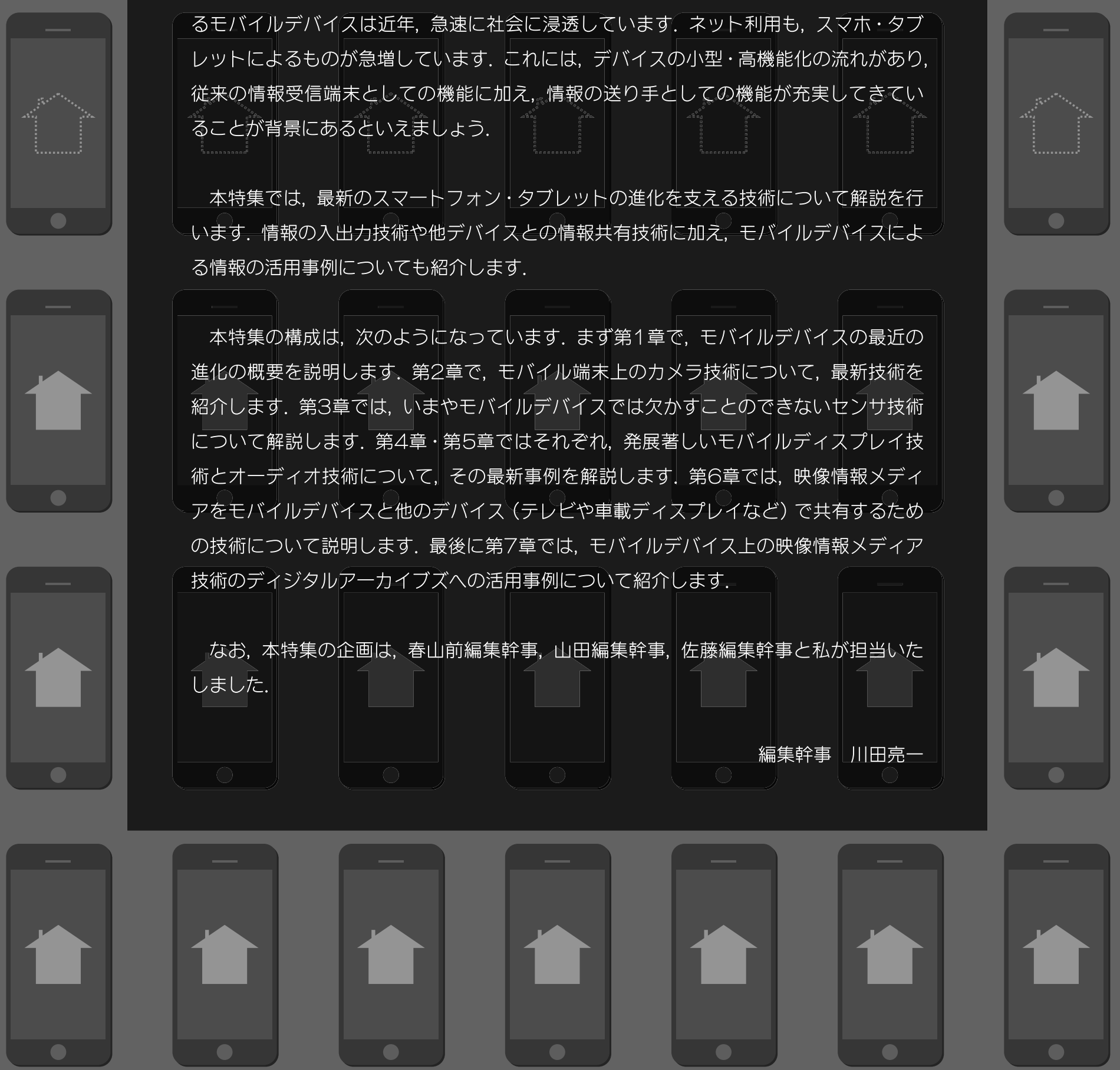


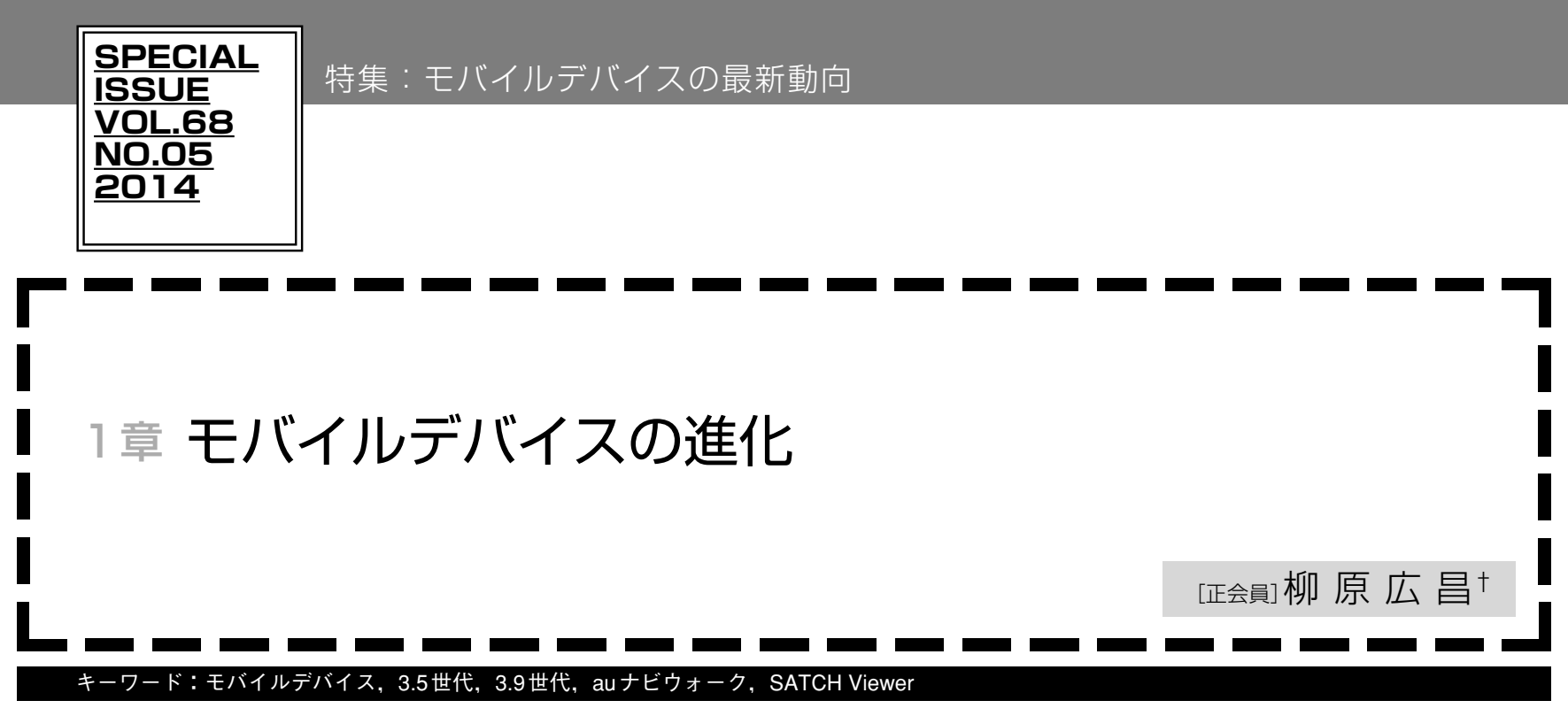

\section{1. まえがき}

1901年 (明治 34 年) の報知新聞に掲載された「二十世紀の 豫言」1)の中で,「マルコーニが発明した無線電信は一層進 歩して, 無線電話で東京からロンドンやニューヨークの友 人と自由に会話できるようになる (意訳)」とあるが，今で は携带電話で自由に国際電話やメール，チャット，Web 閲 覧，テレビ電話までできる時代となった．端末においては， 自動車電話機から始まり, 持ち歩けるショルダー型のポー タブル電話機，手のひらに乗るようなハンディタイプへと 進化し, タブレット型や腕時計型など, 大きさ, 形状だけ でなく身に付け方や使い方も多様化し, 各種内蔵デバイス (カメラ, GPS， ワンセグ, FeliCa, WiFiなど多数) ととも に多機能端末として利用されている。ささらには，スマート フォンで自由に好きなアプリをダウンロードして, 個人毎 に機能拡充が簡単にできるパーソナルデバイスへと進化し たとも言える。こうした急速な発展を遂げているモバイル デバイスの進化について, その性能, 機能, ユースケース, および開発環境の側面から以下に述べる.

\section{2. モバイルデバイスの性能面における進化}

近年, モバイルデバイスの性能・機能は急速な進化を遂 げており, 主に携帯電話端末における, ワイヤレス通信の 方式拉よびその伝送速度と, アプリケーションプロセッサ の処理速度の二つの側面が, モバイルデバイスの進化を牽 引しているといえる.

\section{1 ワイヤレス通信の進化}

日本では 2001 年から 2002 年にかけて, 下り最大数百 kbpsのデー夕通信に対応した, W-CDMA やCDMA2000 $1 \mathrm{X}$ といった第 3 世代携带電話が登場した. その後, CDMA 1X EV-DO HSDPA/HSUPA 等の第 3.5 世代と呼ばれる, 数Mbps 程度の伝送速度を実現するより高速なデー夕通信 方式が登場した。そして，2009年にWiMAX，2010年に LTE (Long-Term Evolution) といった第3.9世代（一般に第

$\dagger$ KDDI 研究所
"Evolution of Mobile Devices" by Hiromasa Yanagihara (KDDI R\&D
Laboratories, Tokyo)

$356(2)$
4 世代と呼ばれる) デー夕通信の提供が開始され，数十 Mbpsレベルの家庭向け光ファイバに匹敵する伝送速度が 実現されている，さらに，2000年代後半より登場している スマートフォンに拀いては, IEEE 802.11準拠の無線LAN （Wi-Fi）も併せて採用されるようになり，通信性能におい てPCに限りなく近づいている。これにより，Wi-Fiとモバ イルデー夕通信を併せ持ったモバイルデバイスが爆発的な 普及を遂げており，時刻や場所を問わず高速なデー夕通信 が快適に利用できるようになっている.

\section{2 プロセッサ性能の進化}

モバイルデバイス，特に携帯電話端末においては，より 高速な通信速度をさらに活用できるよう，プロセッサの処 理速度も急速に進化している. 第3世代携帯電話が登場した ばかりの 2000 年代初頭においては，まだ組込み向けに小型 から省電力に設計されたプロセッサが採用されていること が多く, 比較的短めのメールの読み書きや, 小型の画面に 適した簡易なゲームなどといったアプリケーションが動作 可能であった．その後, 2000 年代後半にスマートフォンが 普及するようになり，OS (Operating System) もPCに近い 構造のものが採用されるようになると，モバイルデバイス 向けプロセッサの動作速度の進化が大幅に加速した．例え ば，2009年〜2010年に大多数のスマートフォンで採用され た, ARM社のCortex-A8の動作速度は 2000 MIPS $(1.0 \mathrm{GHz}$ 動作時) であるが，これはおよそIntel社のPC向けプロセッ サである Pentium III (600 MHz 動作時) に匹敵する. 現在も な抢，モバイルデバイス向けのプロセッサは急速に進化を 続けており，2013年には64ビットプロセッサも登場するな ど，PCの性能に限りなく近づいてきている.

3. モバイルデバイスのユースケースの変化

前章で述べたように，モバイルデバイスの通信速度や処 理性能は飛躍的に進化し, PCクラスの性能に肉薄しつつ ある.これにより, モバイルデバイスの用途も, 第 3 世代 携帯電話が登場した当初はメールの読み書き，モバイル向 けに最適化した簡易Webサイトの閲覧等であったのが，現 在では多彩な視覚効果や多様な機能を伴う高度なアプリ ケーションに拡大している．特に，PCにないモバイルデ 映像情報メディア学会誌 Vol. 68, No. 5, pp. 356〜358（2014） 


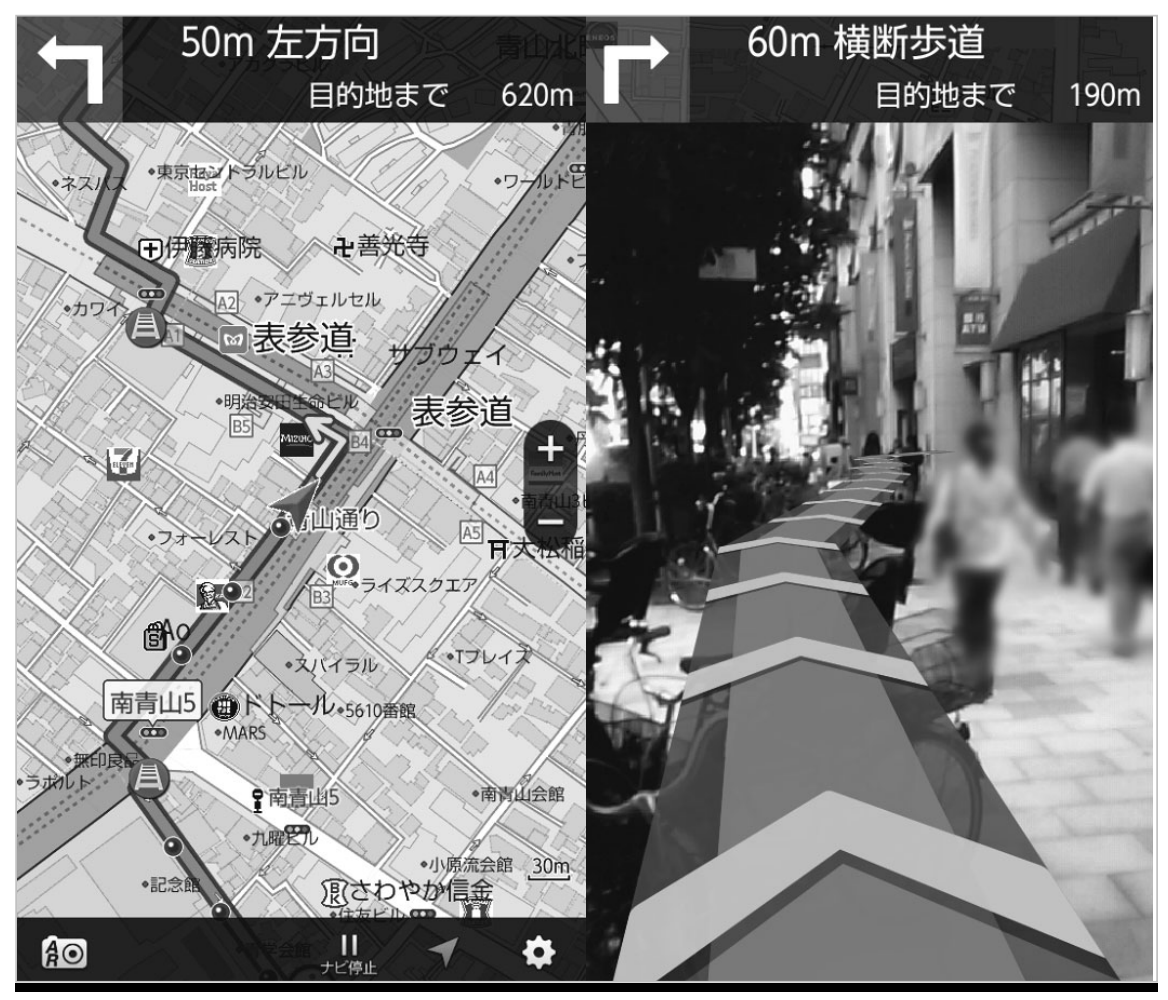

図 1 ナビゲーションアプリの例(auナビウォーク)2

Navigation Engine by NAVITIME JAPAN

地図：昭文社/@ゼンリン/国土地理院, 交通情報：VICS/JARTIC

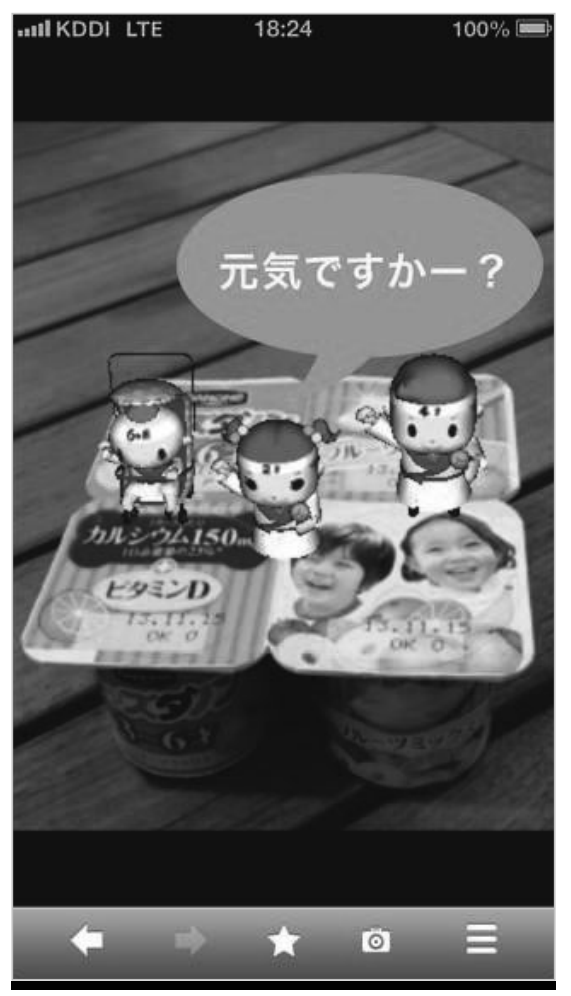

図2 AR (拡張現実)アプリの例 (SATCH Viewer) ${ }^{3)}$
バイスの特徴として，手で持ち運びができる小型のデバイ ス内にカメラや加速度センサ, GPSなど多様な応用デバイ スを内蔵している点が挙げられる。これにより, 移動先で カメラの映像を取り込んだり, GPSや加速度センサからデ バイスの位置や移動に関する情報を取得したりするなど, 従来のPCでは考えられないような幅広い機能や利用シー ンに発展している.

例えば，ナビゲーションアプリでは，GPSでリアルタイ ムにモバイルデバイスの位置取得を行いながら, デバイス の向きを加速度センサで検知して進行方向に合わせて地図 を回転表示させたり, 進行方向を 3D 表示でわかりやすく 表示したりすることが可能となっている(図1).

処理速度の向上により, リアルタイム画像処理を活用し たアプリケーションもモバイルデバイス上で実現可能と なっている．例えば，カメラからリアルタイムに映像フ レームを取得して画像認識やカメラパラメータの推定を行 い, 3Dキャラクタとの重ね合わせを行う, いわゆる $\mathrm{AR}$ (仮想現実) アプリケーションもモバイルデバイスで実際に 提供されており，広く活用されている(図2).

4. モバイルアプリケーションの開発環境の変化 モバイルデバイスの性能の進化に伴い，アプリケーショ ンの開発環境も大きく変化しつつある. かつてのモバイル デバイスでは，限られたメモリーにおいて効率よくアプリ ケーションを動作させるため, $\mathrm{C} / \mathrm{C}++$ 言語でメモリーの
確保と開放を開発者自身が綿密に行うように実装すること が必須であった。近年は，モバイルデバイスの搭載メモ リーが大幅に増加しており, さらに，OSや開発環境が高 度化することによって，開発者自身が意識すべき点が大幅 に軽減されている，例えば，JavaやObjective-C等といっ た， $\mathrm{C} / \mathrm{C}++$ に比べて柔軟性や安全さの高いプログラミン グ言語が広く採用されるようになっている. また，ガベー ジコレクションやARC (Automatic Reference Counting) といった，不要になったメモリーを動的に開放する仕組み が一般的に用いられるようになっている.

一方, PCのようなマルチウィンドウアプリケーションと 異なり，モバイルデバイスでは限られた画面サイズを有効 活用するため, 一つのアプリケーションが画面全体を専有 することが一般的となっている。これにより，アプリケー ションを切替えることによって, 非表示になったアプリ ケーションが，メモリーの空き状況に応じて自動的に終了 され, メモリー解放も自動的に行われるようになっている. したがって，このようなアプリケーションの状態遷移を意 識して，データが失われないよう適切な処理を実装するこ とが,アプリケーション開発者にとって必須となっている. 処理能力の向上により，モバイルデバイスのWebブラウ ザの動作性能も飛躍的に進歩している。これにより， HTML5を用いてWebアプリケーションを開発すること で，デバイスのOSを問わず共通にアプリケーションを動 作させることが可能となっている. 現状ではセキュリティ 
等の制限により, Webアプリケーションで実現可能な機能 に限りがあるが，互換性の高さや開発の容易さなど，さま ざまな観点で多くの開発者から注目を集めており, 今後の 発展が期待されている.

\section{5. むすび〜今後の期待〜}

ここ十数年の間に急速な発展を遂げているモバイルデバ イスの進化について, その性能, 機能, ユースケース, お よび開発環境の側面から述べた. 今後の兆しとして周辺デ バイスとの連携が挙げられる. CES2014の一つのトピック でもあったウェアラブルデバイス（リストバンド，ネック レス, グラス, シューズ等) は, 歩数, 移動距離, 消費力 ロリー, 脈拍, 体温, 食事内容, 睡眠時間・深さといった バイタル・活動量等のいわゆるライフログ情報を収集して スマートフォンに送り，その上で見易く統計管理でき， ユーザのライフスタイル (フィットネス, ヘルスケア等) の気付きを与えるものとして注目されている.このように
スマートフォンが種々のセンサデバイスの中核となって動 作し，Siriのような対話機能がより高度化し，ユーザ個人 のパーソナルゲートウエイとして人に寄り添い, さり気な く生活をサポートする，そのような時代が近い将来にやっ て来ることを大いに期待したい.

(2014年1月 26 日受付)

\section{〔文 献〕}

1）“二十世紀の豫言”，報知新聞社明治 34 年 (1901 年) 正月版掲載, http://hochi.yomiuri.co.jp/info/company/yogen.htm

2) auナビウォーク, http://www.au.kddi.com/mobile/service/ smartphone/life-support/naviwalk/

3) SATCH Viewer, http://viewer.satch.jp/

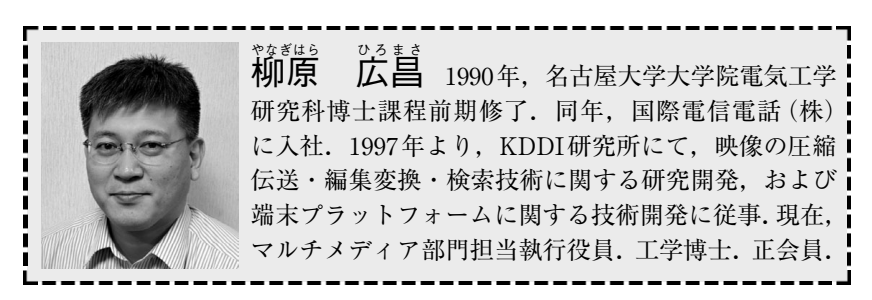

